Merancang Strategi Human ... (Eleonora Chrysenny Hutagalung)

\title{
MERANCANG STRATEGI HUMAN RESOURCE RETENTION PADA PT. XYZ
}

\author{
Eleonora Chrysenny Hutagalung \\ Program Studi S2 Magister Manajemen Eksekutif \\ Sekolah Tinggi Manajemen PPM
}

\begin{abstract}
Sejak tahun 2008, seiring dengan terus menurunnya kinerja di PT. XYZ, lebih dari sepertiga karyawan mengundurkan diri. Kebanyakan karyawan tersebut adalah karyawan manajerial yang memiliki pengaruh pada perusahaa. Survey, menunjukkan bahwa ada alas an mengundurkan diri adalah ketidakpuasan karyawan yang menyebabkan mereka enggan terlibat sepenuhnya atau engage dengan perusahaan. Ketidakpuasan tersebut disebabkan oleh rendahnya perhatian perusahaan pada aspek-aspek pelatihan dan pengembangan karyawan, pengembangan karir, kompensasi dan benefitserta penilaian manajemen/kinerja. Penelitian ini menunjukkan bahwa di PT. XYZ terdapat empat dari delapan faktor yang mempengaruhi keputusan karyawan untuk tetap bertahan di dalam perusahaan dengan kondisi ekomomi yang kurang menguntungkan. Keempat faktor tersebut adalah lingkungan kerja yang harmonis, kerjasama yang efektif, perhatian perusahaan terhadap kesehatan dan kesejahteraan, dan kesempatan meningkatkan kinerja.Berdasarkan hasil survey, dirancang suatu strategi untuk meningkatkan human resources retention pada $P T$. XYZ..
\end{abstract}

Keywords:

Kepuasaan karyawan, human resources retention 


\section{PENDAHULUAN}

PT. XYZ telah berdiri sejak tahun 1975, dan berdasarkan data perusahaan per Februari 2010, PT. XYZ telah memiliki 77 buah kapal. Seiring dengan ekspansi bisnisnya, PT. XYZ menjadi perusahaan yang semakin berkembang sejak melakukan Initial Public Offering (IPO) pada bulan Juni 1995. PT. XYZ mulai dikenal publik secara luas dimana ditunjukkan dengan peningkatan kinerja keuangan yang signifikan sejak tahun 2004. Akan tetapi terjadinya krisis ekonomi global di tahun 2008 memberikan dampak yang sangat besar terhadap keuangan perusahaan. Ditambah lagi dengan perusahaan mengambil produk derivatif.

Oleh karena itu, berbagai kebijakan finansial perusahaan yang selama ini diterapkan mulai diperketat dengan melakukan efisiensi di berbagai bidang, terutama yang berkaitan dengan lingkup sumber daya manusia. Program-program pelatihan dan pengembangan karyawan mulai tidak dilakukan sejak dua tahun belakangan, begitu juga dengan pemenuhan kebutuhan karyawan baru. Selain itu kebijakan pemberian bonus akhir tahun sebagai bentuk apresiasi kinerja karyawan sudah tidak diberikan sejak tahun 2009. Serta banyak lagi kebijakan dan program SDM lainnya yang tidak dapat terlaksana. Manajemen perusahaan lebih memfokuskan pada perbaikan bisnis dan stabilitas finansial perusahaan.

Pada awal bulan Januari 2010 dilakukan restrukturisasi organisasi secara besar-besaran. Dimana pucuk pimpinan di divisi Fleet ditiadakan, dan beberapa pucuk pimpinan departemen diganti dengan pengangkatan karyawan dari dalam perusahaan. Ironisnya pengangkatan karyawan ini tidak diikuti dengan persiapan yang matang berdasarkan kesiapan untuk menempati posisi jabatan baru, pengenalan pekerjaan baru, latar belakang karyawan, dan lain sebagainya. Akan tetapi dilakukan lebih pada dasar kepercayaan antara pemilik perusahaan kepada karyawan yang ditunjuk untuk menduduki posisi jabatan tertentu. Belum adanya perencanaan jalur karir yang jelas menjadikan posisi seorang karyawan dapat berubah secara tidak menentu. Hal ini juga ditandai dengan belum maksimalnya efek program Management Training (MT) yang diadakan perusahaan. Peserta MT yang semula ditujukan sebagai second layer bagi perusahaan banyak yang belum diperhatikan perencanaan jalur karirnya.

Perubahan jabatan dan organisasi yang tidak terencana memberikan dampak bagi karyawan yang bersangkutan maupun bagi seluruh karyawan. Hal ini dapat dilihat dari tingginya tingkat turn over karyawan. Data menunjukkan ada karyawan yang dipromosikan justru lebih cepat mengajukan pengunduran diri dari perusahaan. Disamping itu 1/3 karyawan yang mengundurkan diri adalah pada level manajerial (Supervisor-Manager). Belum lagi fakta dimana timbul keresahaan dan situasi yang kurang kondusif dari efek perubahan organisasi yang mendadak. Karyawan merasa situasi kerja tidak lagi menguntungkan sehingga mereka mengajukan pengunduran diri untuk mencari posisi aman di luar perusahaan.

Peningkatan angka turn over karyawan ini kemudian secara langsung maupun tidak langsung mempengaruhi kinerja PT. PT. XYZ dan menimbulkan beberapa masalah baik secara internal maupun eksternal perusahaan. Secara internal perusahaan tampak bahwa kedisiplinan karyawan dalam bekerja menurun secara signifikan Sementara secara eksternal perusahaan terjadi menurunnya kepercayaan pelanggan/pasar dalam menggunakan jasa perusahaan, juga kepercayaan bank dalam memberikan pinjaman modal usaha. 
Kemudian muncul pertanyaan apakah upaya yang dapat dilakukan perusahaan untuk meng-engage atau menahan karyawannya dalam situasi ekonomi yang buruk saat ini, sehingga tingkat turn over karyawan dapat ditekan. Sementara Departemen HRD tidak pernah diikutsertakan dalam menyusun dan mengimplementasikan strategi bisnis perusahaan.

\section{TINJAUAN PUSTAKA}

\subsection{Manajemen Sumberdaya Manusia}

Manajemen sumberdaya manusia (MSDM) adalah suatu proses menangani berbagai masalah pada ruang lingkup karyawan, pegawai, buruh, manajer dan tenaga kerja lainnya untuk dapat menunjang aktifitas organisasi atau perusahaan demi mencapai tujuan yang telah ditentukan. MSDM juga didefinisikan sebagai ilmu dan seni mengatur hubungan dan peranan tenaga kerja secara efisien dan efektif sehingga tercapai tujuan bersama perusahaan, karyawan dan masyarakat. Menurut Stoner MSDM adalah suatu prosedur yang berkelanjutan yang bertujuan untuk memasok suatu organisasi atau perusahaan dengan orang-orang yang tepat untuk ditempatkan pada posisi dan jabatan yang tepat pada saat organisasi memerlukannya.

Menurut Fajar \& Heru (2010)

MSDM penting bagi semua organisasi untuk menghindarkan dari hal berikut:

1. Kesalahan penempatan orang untuk suatu pekerjaan.

2. Turn over yang tinggi.

3. Rendahnya kinerja karyawan dalam melaksanakan pekerjaannya.

4. Pembuangan waktu untuk pembicaraan yang tidak ada kaitannya dengan pekerjaan.

5. Diskriminasi dalam memperlakukan karyawan.

6. Angka kecelakaan kerja yang tinggi.
7. Ketidakadilan dalam pengupahan.

8. Ketidakberdayaan karyawan.

Agar tujuan SDM memberikan kontribusi yang lebih besar bagi organisasi untuk meraih keunggulan kompetitif diperlukan strategi yang tepat dalam perencanaan SDM secara terpadu. Kegiatan dari strategi SDM didasarkan pada kerjasama antar departemen SDM secara terpadu dengan manajer lini serta keterlibatan manajemen puncuk dalam menjelaskan visi dan misi organisasi yang dapat dijabarkan dalam tujuan bisnis yang strategis.

$$
\text { MSDM yang strategis (Hariandja, }
$$

2007) didefinisikan sebagai adanya keterkaitan antara SDM dengan tujuan dan sasaran strategis untuk meningkatkan kinerja bisnis dan mengembangkan budaya organisasi yang mendorong inovasi dan fleksibilitas untuk memampukan organisasi dalam mencapai tujuannya. Definisi ini mengatakan bahwa departemen SDM harus menjadi mitra strategis. Oleh karena itu departemen SDM harus terlibat dalam perumusan strategi perusahaan.

\subsection{Retensi Karyawan}

Carsen, (2002) menyatakan bahwa retensi karyawan secara sederhana mengacu pada berapa banyak karyawan anda saat ini yang dapat bertahan dalam jangka waktu tertentu. Lebih lanjut dijelaskan oleh Phillips \& Connel (2003) bahwa retensi adalah karyawan yang tersisa di dalam organisasi. Retensi yang tinggi diharapkan pada kebanyakan kelompok pekerjaan.

Mengelola retensi adalah suatu tantangan pasti untuk setiap organisasi. Meskipun dalam kondisi ekonomi yang sedang bergerak perlahan, kebanyakan para eksekutif SDM menemukan bahwa menarik dan menahan karyawan potensial (talent) menjadi permasalahan yang besar. Dalam studi yang dilakukan selama resesi tahun 2001 - 2003, 90\% dari 109 eksekutif yang 
disurvei mengatakan bahwa mereka menemukan kesulitan untuk menarik dan menahan orang-orang terbaik yang dimiliki perusahaan (Phillips \& Connel, 2003).

Retensi karyawan adalah salah satu ukuran utama dari tingkat kesehatan sebuah perusahaan, entah yang mapan maupun startup. Maka berikut ini adalah hal-hal yang perlu diperhatikan untuk membuat para karyawan handal betah di perusahaan (Guntar, 2008) yaitu:

1. Ekspektasi kerjaan yang jelas dan terkomunikasikan.

2. Kualitas kepemimpinan dan supervisi terhadap karyawan.

3. Keleluasaan mengungkapkan isi hati dan kepala.

4. Pendayagunaan bakat dan skill alami karyawan.

5. Peluang peningkatan kompetensi.

Bruce (2008) memberikan sembilan

saran untuk mempertahankan karyawan yaitu:

1. Perlakukan para karyawan layaknya partner.

2. Utarakanlah harapan dan tujuan anda dengan jelas.

3. Utamakanlah pengembangan kinerja karyawan, bukan pengawasan terhadap mereka.

4. Luangkan waktu untuk mengenali kebutuhan manusiawi karyawan anda.

5. Berinvestasilah dalam diri karyawan anda dan rangsanglah perkembangan personal dan profesional mereka.

6. Hargai partisipasi, ide-ide baru, dan pendekatan-pendekatan inovatif karyawan.

7. Hargailah kesalahan dengan mentolerasikan kesalahan dan eksperimeneksperimen intelektual.

8. Pertahankan suasana kerja yang menyenangkan.

9. Aktifkan mekanisme penghargaan kerja karyawan.

\subsection{Employee Engagement}

Menurut Cook (2008) employee engagement terwujud dari hasrat dan energi yang dimiliki oleh para karyawan untuk memberikan yang terbaik bagi organisasinya untuk dapat melayani pelanggannya. Karyawan yang merasa ter-engage akan terinspirasi oleh pekerjaan mereka dan akan melakukan pendekatan yang berfokus pada pelanggan, mereka memperdulikan masa depan perusahaan dan siap untuk menginvestasikan usaha mereka sendiri agar organisasi dapat mencapai kesuksesannya.

Insitute of Employee Studies (2004) mendefinisikan employee engagement adalah suatu sikap positif dari karyawan terhadap organisasi tempat dirinya bekerja. Karyawan yang "terpacu" akan peduli terhadap bisnis organisasi dan bekerja secara tim untuk meningkatkan performansi organisasi. Lebih jauh Benthal (2007) mengartikan employee engagement sebagai suatu komitmen karyawan terhadap organisasi untuk mensinergikan waktu dan tenaga yang dimiliki dalam usaha meningkatkan performansi diri dan organisasi ke arah yang lebih baik.

Dalam penelitian lain yang dilakukan Fitri \& Suziani (2010), engagement dapat disimpulkan dari seberapa positif karyawan berpikir tentang organisasi; perasaan tentang organisasi; dan secara proaktif berusaha untuk mencapai tujuan organisasi untuk pelanggan, rekan kerja dan pihak-pihak lain yang berkepentingan. Lebih lanjut Cook (2008) mengidentifikasi karyawan yang ter-enggage secara aktif adalah karyawan yang mengalami cognitive engagement, emotional engagement, physical engagement dan advocacy.

IES (Institute for Employment Studies) dalam penelitiannya melalui IES Survey tahun 2003, didapatkan bahwa kepuasan kerja merupakan salah satu pemicu terciptanya engagement (Fitri \& Suziani, 
2008). Selain itu pemimpin dan lingkungan kerja dalam organisasi tempat individu bekerja sangat berpengaruh terhadap employee engagement (Harry \& Ma'mun, 2008).

Faktor dorongan utama dalam hal employee engagement adalah perasaan dinilai/dihargai dan diikutsertakan dalam perusahaan. Menurut penelitian yang dilakukan oleh IES (2004), yang telah melakukan penelitian terhadap lebih dari 10.000 karyawan di 12 organisasi kesehatan nasional di Inggris, terdapat beberapa faktor utama yang dapat mendorong penciptaan suatu pekerja yang merasa di-engage. Faktor-faktor utama tersebut adalah :

1. Mengikutsertakan karyawan dalam hal pengambilan keputusan perusahaan.

2. Mendorong karyawan yang merasa mampu untuk menyuarakan ide-ide yang dimiliki, pemimpin mau mendengar pandangan mereka dan menilai pandangan tersebut secara jujur dan terbuka.

3. Memberikan kesempatan kepada karyawan untuk dapat meningkatkan kinerja.

4. Mendorong organisasi untuk dapat meningkatkan perhatian terhadap kesehatan dan kesejahteraan karyawan.

Lebih lanjut IES mengatakan bahwa terdapat beberapa faktor pendukung lain yang dapat meningkatkan employee engagement, antara lain:

1. Kualitas yang baik dari pemimpin perusahaan. Para pemimpin peduli terhadap karyawan, menjaga komunikasi yang baik dengan bawahan, mendorong untuk dapat bekerja lebih baik, mendengarkan aspirasi bawahan terkait dengan peningkatan karir, dan memberikan kesempatan yang luas dalam hal pelatihan dan pengembangan karir.
2. Membuka komunikasi dua arah. Dalam hal ini, perusahaan memberikan kesempatan kepada karyawan untuk dapat menyuarakan ide-ide yang dimiliki dan menyarankan suatu hal yang lebih baik dalam bekerja. Dan tentu saja perusahaan tetap mengarahkan mereka agar ide-ide tersebut dapat bermanfaat bagi orang lain dan peningkatan wilayah bisnis perusahaan.

3. Kerja sama yang efektif dalam perusahaan. Perlunya kerjasama yang efektif antara departemen yang ada dalam perusahaan.

4. Fokus terhadap pengembangan karyawan. Perlu diciptakan suatu kondisi, bahwa karyawan merasa dirinya diperhatikan oleh perusahaan untuk berkembang dalam jangka waktu yang lama dan memberikan kesempatan yang adil bagi setiap karyawan.

5. Sebuah komitmen terhadap kesejahteraan karyawan. Menunjukkan suatu itikad yang baik terhadap kesehatan dan keselamatan kerja secara serius, meminimalkan kecelakaan kerja, mengambil tindakan yang efektif dalam menghadapi masalah.

6. Terbuka akses terhadap kebijakan perusahaan dan SDM. Dalam hal ini pemimpin komit terhadap penilaian kinerja, kesamaan kesempatan, dan persaudaraan yang sehat.

7. Keterbukaan dalam gaji dan tunjangan. Karyawan perlu diberitahukan tentang perbandingan gaji dan tunjangan yang didapatkan.

8. Lingkungan kerja yang harmonis. Perlu ditingkatkan solidaritas pada karyawan untuk saling berempati dan menolong kesulitan karyawan lain. 


\section{METODOLOGI}

\subsection{Kerangka Analisis}

Langkah awal yang dilakukan adalah mempelajari dan mengidentifikasi visi dan misi perusahaan sebagai acuan dalam mempelajari sasaran perusahaan yang terkait dengan kondisi organisasi saat ini. Sasaran perusahaan tersebut akan dipelajari serta diperkuat oleh data keuangan, kegiatan operasional, bisnis dan sumberdaya manusia. Selanjutnya data dilengkapi juga oleh faktorfaktor yang mempengaruhi keputusan karyawan untuk bertahan di perusahaan. Agar penulis dapat membuat rancangan strategi MSDM dan implementasinya yang berorientasi pada upaya human resource retention, maka perlu mengacu serta mempelajari kesenjangan strategi MSDM saat ini dan ideal untuk mendukung situasi organisasi kedepannya.

Berdasarkan hasil analisa data yang dilakukan secara menyeluruh, diharapkan upaya untuk mempertahankan karyawan yang potensial dan tidak potensial sekalipun akan lebih terarah dan terencana sesuai dengan sasaran dan kebutuhan strategi bisnis perusahaan.

\subsection{Metode Pengumpulan Data}

Berikut dibawah ini adalah uraian mengenai metode pengumpulan data primer, yaitu :

1. Kuesioner

Penyebaran kuesioner dilakukan pada karyawan level Staff - Manager secara random (acak). Penyebaran kuesioner ini bertujuan untuk mengidentifikasi tingkat employee engagement, faktor-faktor utama yang mempengaruhi employee engagement dan juga mengetahui pendapat karyawan terhadap strategi bisnis dan strategi MSDM yang dibutuhkan agar karyawan tetap dapat bertahan dalam organisasi.
2. Wawancara

Teknik wawancara yang digunakan adalah semi terstruktur. Wawancara dibedakan menjadi 3 jenis, yaitu :

a. Wawancara Board of Director (BOD)

Bertujuan untuk mempelajari kondisi perusahaan dari segi bisnis, keuangan, operasional dan SDM. Mempelajari dan mengidentifikasi strategi bisnis dan sasaran perusahaan yang disusun dan dilaksanakan dalam dua tahun mendatang (2010-2012).

b. Wawancara Karyawan Bertujuan untuk menggali faktorfaktor utama yang mempengaruhi employee engagement secara mendalam serta apa yang mereka harapkan dari perusahaan dalam situasi saat ini agar mereka tetap dapat bertahan dengan perusahaan.

c. Wawancara Karyawan Resign

Bertujuan untuk mengetahui penyebab karyawan resign dalam situasi saat ini dan hal-hal yang perlu diperbaiki perusahaan menurut opini mereka.

\subsection{Metode Pengambilan Sampel}

Metode pengambilan sampel yang digunakan adalah teknik sample random sampling yaitu sampel dipilih langsung dari populasi dan besar peluang setiap anggota populasi untuk menjadi sampel sama besar. Pengambilan sampel pada penyebaran kuesioner ditentukan berdasarkan pada rumus perhitungan sampel Slovin (Sevilla, 1993) yaitu dari jumlah 267 orang karyawan, dengan taraf signifikan 5\%, maka sampel yang didapat adalah 160 orang karyawan. Pengambilan sampel pada wawancara sebanyak 4 orang karyawan dan 3 orang karyawan yang sudah resign.

Beberapa kriteria ditentukan agar populasi menjadi homogen adalah:

1. Level Junior Staff - Manager.

2. Usia antara $24-50$ tahun. 
3. Pendidikan minimal Diploma.

4. Masa kerja minimal 2 tahun.

5. Status karyawan tetap.

\subsection{Metode Analisis Data}

Teknik analisis data yang digunakan bersifat sederhana yaitu dengan mencari prosentase/rata-rata (mean) dari faktor-faktor yang diukur. Sementara uji validitas dan reliabilitas kuesioner menggunakan perhitungan Alpha Cronbach dan Product Moment Pearson.

\section{HASIL ANALISIS DATA}

\subsection{Data Primer}

\subsubsection{Kuesioner}

Kuesioner yang terkumpul berjumlah 119 buah. Hal ini dikarenakan jumlah sampel yang telah ditetapkan disaring kembali berdasarkan kriteria sampel yang telah ditentukan dan ada beberapa kuesioner tidak kembali.

Berdasarkan hasil uji validitas dan reliabilitas tersebut maka didapatkan bahwa kuesioner yang disebarkan memiliki tingkat validitas yang tinggi. Dimana hanya terdapat 1 item pertanyaan yang tidak valid (gugur). Selanjutnya didapatkan Koefisien Reliabilitas sebesar 0,9251. Nilai tersebut menunjukkan sudah lebih besar dari 0,60, maka data hasil kuesioner memiliki tingkat reliabilitas yang baik. Dengan kata lain hasil data kuesioner tersebut dapat dipercaya.

Data dari hasil kuesioner mengenai faktor-faktor utama penyebab employee engagement pada karyawan PT. XYZ sehingga mereka bertahan dalam kondisi perusahaan saat ini adalah:

1. Lingkungan kerja yang harmonis, $(19,42 \%)$.

2. Kerjasama yang efektif (12,72\%).

3. Perhatian terhadap kesehatan dan kesejahteraan (11,83\%).
4. Kesempatan meningkatkan kinerja $(10,04 \%)$.

Sementara aspek-aspek yang perlu disempurnakan dalam bidang SDM agar mereka tetap dapat bertahan dengan perusahaan dalam jangka waktu yang panjang adalah:

1. Pelatihan dan pengembangan karyawan (21,08\%).

2. Pengembangan karir (20,82\%).

3. Kompensasi dan benefit $(19,02 \%)$.

4. Penilaian manajemen/kinerja (14,40\%).

\subsubsection{Wawancara}

Hasil dari wawancara adalah:

1. Pengambilan keputusan yang terkait dengan pekerjaan yang mengandung resiko tinggi dilakukan secara berjenjang dan dalam kontrol atau sepengetahuan atasan berikutnya. Untuk efektivitas pekerjaan yang tidak beresiko terhadap perusahaan dapat dilakukan sendiri oleh masing-masing pemegang jabatan.

2. Sistem komunikasi yang dilakukan juga bersifat berjenjang, dimana komunikasi yang dilakukan bersifat dua arah untuk karyawan dengan level jabatan sejajar. Namun bersifat satu arah yang berupa instruksi antara atasan dan bawahan. Akan tetapi antara atasan dan bawahan dapat terbuka untuk menyampaikan aspirasinya masing-masing, hanya saja adanya keseganan menjadikan kadang aspirasi tersebut tidak tersampaikan secara baik.

3. Pada dasarnya setiap karyawan berhak dan dapat menyampaikan ide dan pemikirannya, akan tetapi ide dan pemikiran tersebut akan tersalurkan hanya sampai dengan atasan langsung dan jarang sekali sampai kepada atasan berikutnya. Hal ini yang sepertinya menjadikan aspirasi dari bawah kadang sering tidak terealisasikan secara baik. 
4. Hal-hal yang menjadikan karyawan tidak bertahan dalam kondisi perusahaan saat ini adalah kurangnya informasi yang informatif kepada semua level jabatan, sehingga karyawan merasa resah dan mencari tahu sendiri kepada sumbersumber yang tidak sepenuhnya benar.

5. Issue kompensasi dan benefit yang kurang fair juga menjadi dasar mengapa karyawan merasa tidak puas dengan perusahaan dan memutuskan untuk resign. Begitu juga dengan belum terlaksananya sistem reward and punishment yang seimbang.

6. Sementara hal yang dapat membuat karyawan tetap bertahan dengan perusahaan adalah karena lingkungan yang sangat harmonis, dimana ada kedekatan dan keakraban, serta kerjasama yang dirasakan cukup baik di dalam tim maupun antar departemen. Selain itu belum adanya kesempatan yang ditawarkan dari luar perusahaan. Sementara ada juga yang menyatakan bahwa mereka sudah berada di confort zone dimana mereka enggan untuk beradaptasi lagi dengan lingkungan baru, dengan masa kerja yang sudah lama menjadikan mereka loyal terhadap perusahaan.

\subsection{Data Sekunder}

\subsubsection{Visi dan Strategi Perusahaan}

Perusahaan memiliki visi yaitu:

1. Menjadi perusahaan yang dominan dalam industri pelayaran Indonesia dan ikut berperan dalam arena pelayaran internasional.

2. Membangun hubungan jangka panjang dengan pelanggan dengan memberi pelayanan berorientasi pelanggan terbaik melalui pengangkutan tepat waktu, endto-end logistic solution.

3. Ikut meningkatkan pembangunan transportasi angkutan laut nasional dalam pengertian luas, termasuk pengembangan sumber daya manusia dan pembangunan masyawakat.

Dalam situasi ekonomi perusahaan saat ini tidak ada perubahan visi perusahaan. Sementara strategi yang sedang difokuskan dalam upaya mempertahankan perusahaan adalah refinancing dan bekerja sama dengan Financial Consultant untuk mencari investor baru yang ditargetkan pada bulan September 2010. Strategi operasional yang dilakukan adalah analisa dan perbaikan sistem kontrol dalam pengelolaan aset perusahaan seperti kapal dan lain-lain. Strategi pemasaran yaitu target pencapaian penjualan minimal adalah sama dengan tahun-tahun sebelumnya. Untuk strategi SDM adalah pengoptimalan sumberdaya manusia yang ada dengan melakukan upaya-upaya retention.

\subsubsection{Data Turn Over Karyawan}

Berdasarkan data turn over karyawan maka karyawan resign pada level Manajerial sebanyak 37,5\% dan level NonManajerial sebanyak 62,5\%. Data tersebut menunjukkan bahwa lebih dari 1/3 karyawan yang resign adalah pada posisi jabatan yang memiliki pengaruh pada perusahaan.

Secara menyeluruh kemudian dapat disimpulkan bahwa terjadi peningkatan turn over yang sangat signifikan pada tahun 2010 jika dibandingkan dengan tahun 2008-2009, dimana merupakan awal terjadinya krisis ekonomi global yang diikuti dengan permasalahan derivatif, kemudian semakin meningkat setelah terjadi restrukturisasi organisasi yang dilakukan secara mendadak. Jumlah karyawan di level Manajerial yang resign pada tahun 2008 sebanyak 47,1\%, pada tahun 2009 sebanyak 16,7\% dan pada tahun 2010 meningkat menjadi 53,8\%. Sementara pada level Non-Manajerial tercatat karyawan yang resign pada tahun 2008 sebanyak 52,9\%, pada tahun 2009 meningkat menjadi $83,3 \%$ dan pada tahun 
2010 menurun menjadi 46,2\%.

\subsubsection{Hasil Exit Interview}

Berdasarkan informasi yang didapat melalui data exit interview diketahui bahwa pengembangan karir (21\%) serta kompensasi dan benefit (26\%) menjadi hal yang juga mempengaruhi alasan karyawan untuk meninggalkan perusahaan. Selain aspek pelatihan dan pengembangan karyawan serta penilaian manajemen / kinerja yang juga diberikan perhatian sebesar $16 \%$.

Berdasarkan hasil dari data primer maupun data sekunder, maka dapat dinyatakan bahwa faktor utama yang membuat karyawan merasa engage dengan perusahaan adalah terciptanya lingkungan yang nyaman dan tentram, dimana ada kedekatan dan keakraban antara satu karyawan dengan karyawan yang lainnya. Untuk itu kerjasamapun tercipta cukup baik di dalam tim maupun antar departemen. Akan tetapi lingkungan kerja yang kondusif saja tidak cukup untuk dapat menahan karyawan agar tetap bertahan dengan perusahaan dalam situasi perusahaan saat ini. Hal itu disebabkan karena manusia adalah makhluk hidup yang memiliki kebutuhan dimana terimplementasi dengan pendapat karyawan terhadap aspek-aspek yang perlu segera dibenahi perusahaan untuk meningkatkan employee engagement, yaitu aspek pelatihan dan pengembangan karir, kompensasi dan benefit, serta penilaian manajemen/kinerja.

Hal tersebut menunjukkan bahwa employee engagement yang sudah terbentuk di dalam diri karyawan harus terus dikelola secara berkesinambungan, terstandarisasi dan terarah. Bentuk dari upaya menahan karyawan yang paling nyata dan dirasakan langsung adalah pada aspek kompensasi dan benefit. Hal ini terlihat dengan tingginya tingkat turn over karyawan sejak terjadi krisis ekonomi global yang secara langsung berdampak pada keuangan PT. XYZ. Disertai dengan kejenuhan karyawan pada karir yang tidak jelas dan kurang berkembang serta semakin jarangnya dilakukan program-program pelatihan dan pengembangan bagi karyawan. Selain itu employee relation menjadi hal terpenting yang harus dilakukan perusahaan terutama saat ini dalam mengupayakan untuk menahan karyawan.

\subsection{Pengembangan Rancangan Strategik}

Berdasarkan hasil pengambilan data yang diolah melalui analisa empiris didapatkan beberapa hal yang perlu diperbaiki untuk mengembangkan perusahaan sehingga dapat dilakukan upaya nyata dalam human resource retention, seperti terdapat pada Tabel 1. 
Tabel 1.

Rancangan Strategi MSDM Prioritas

\begin{tabular}{|c|c|c|}
\hline Strategi MSDM & Kondisi Aktual & Saran Perbaikan \\
\hline $\begin{array}{l}\text { Kompensasi \& } \\
\text { Benefit }\end{array}$ & $\begin{array}{l}\text { - Karyawan kunci resign } \\
\text { karena dapat tawaran gaji } \\
\text { lebih besar dari luar } \\
\text { perusahaan. } \\
\text { - Sistem kompensasi \& benefit } \\
\text { perusahaan tidak fair } \rightarrow \\
\text { kenaikan tahunan sama } \\
\text { prosentasenya untuk tiap } \\
\text { karyawan. } \\
\text { - Standard gaji tidak jelas } \rightarrow \\
\text { upah tidak dilihat dari beban } \\
\text { kerja dan kinerja. }\end{array}$ & $\begin{array}{l}\text { - } \quad \text { Lakukan salary survey } \\
\text { - } \quad \text { Setup salary structure } \\
\text { - } \quad \text { Lakukan rekrutmen } \\
\text { - } \quad \text { Paralel } \\
\quad \text { key person }\end{array}$ \\
\hline $\begin{array}{l}\text { Pengembangan } \\
\text { Karir }\end{array}$ & $\begin{array}{l}\text { - Sistem promosi, mutasi, } \\
\text { rotasi tidak fair } \rightarrow \\
\text { subyektif/senioritas. } \\
\text { - Personal Level (PL) tidak } \\
\text { berkembang (stagnansi). } \\
\text { - Kurang pengembangan } \\
\text { kompetensi dalam bentuk } \\
\text { project-project. } \\
\text { - Parameter kenaikan jabatan } \\
\text { tidak jelas. } \\
\text { - Jabatan tetap dengan masa } \\
\text { kerja lama sekali. }\end{array}$ & $\begin{array}{l}\text { - Career Management } \\
\text { - Job enlargement/ } \\
\text { enrichment }\end{array}$ \\
\hline $\begin{array}{l}\text { Employee } \\
\text { Relation }\end{array}$ & $\begin{array}{l}\text { - Budaya coaching and } \\
\text { counseling tidak ada. } \\
\text { - Informasi mengenai } \\
\text { perusahaan tidak diterima } \\
\text { secara baik dan merata oleh } \\
\text { seluruh karyawan. } \\
\text { - Belum ada media } \\
\text { formal/informal mengenai } \\
\text { mekanisme informasi dan } \\
\text { hubungan kekaryawanan. } \\
\text { - Kurangnya program-program } \\
\text { CSR. }\end{array}$ & $\begin{array}{l}\text { - Optimalkan fungsi leader } \\
\text { dimasing-masing unit/ } \\
\text { departemen } \\
\text { - HR Clinic } \\
\text { - Bangun sistem } \\
\text { komunikasi perusahaan. } \\
\text { - Create program CSR } \rightarrow \\
\text { work-life balance } \\
\text { program }\end{array}$ \\
\hline
\end{tabular}


Peneliti juga memberikan beberapa alternatif pemecahan masalah yang dapat dilakukan bersamaan atau setelah program jangka panjang prioritas terpenuhi, seperti terdapat pada Tabel 2.

Tabel 2.

Rancangan Strategi MSDM Tambahan

\begin{tabular}{|c|c|c|}
\hline $\begin{array}{l}\text { Strategi } \\
\text { MSDM }\end{array}$ & Kondisi Aktual & $\begin{array}{c}\text { Saran } \\
\text { Perbaikan }\end{array}$ \\
\hline \multirow[t]{2}{*}{ HR Planning } & $\begin{array}{l}\text { - Terjadi kekosongan karyawan dalam waktu } \\
\text { yang lama jika ada yang resign. }\end{array}$ & $\begin{array}{l}\text { - Analisa Man } \\
\text { Power } \\
\text { Planning } \\
\text { - HR Forcasting }\end{array}$ \\
\hline & $\begin{array}{l}\text { - Komposisi karyawan tidak disesuaikan. } \\
\text { - Strategi MSDM tidak mengacu pada } \\
\text { Strategi perusahaan. }\end{array}$ & \\
\hline $\begin{array}{l}\text { Rekrutmen dan } \\
\text { Seleksi }\end{array}$ & $\begin{array}{l}\text { - Seleksi kurang ketat } \rightarrow \text { masih ada } \\
\text { karyawan yang tidak kompeten. } \\
\text { - User kurang memahami teknik } \\
\text { wawancara } \\
\text { - Pemenuhan kebutuhan karyawan baru } \\
\text { lambat } \rightarrow \text { butuh bayak waktu. }\end{array}$ & $\begin{array}{l}\text { - Review dan } \\
\text { setup sistem } \\
\text { rekrutmen dan } \\
\text { seleksi } \\
\text { - Training } \\
\text { Behavior Event } \\
\text { Interview untuk } \\
\text { user }\end{array}$ \\
\hline $\begin{array}{l}\text { Pengembangan } \\
\text { Organisasi }\end{array}$ & $\begin{array}{l}\text { - } \quad \text { Model organisasi hirarki. } \\
\text { - } \quad \text { Pamily business beralih ke profesional. } \\
\text { semua level jabatan } \rightarrow \text { kurang informatif. }\end{array}$ & $\begin{array}{l}\text { - Analisa model } \\
\text { organisasi } \\
\text { - Change } \\
\text { management } \\
\text { - Knowledge } \\
\text { mangement }\end{array}$ \\
\hline $\begin{array}{l}\text { Pelatihan dan } \\
\text { Pengembangan }\end{array}$ & $\begin{array}{l}\text { - Pelatihan tidak merata pada semua level. } \\
\text { Perusahaan melihat SDM sebagai cost } \\
\text { bukan asset } \rightarrow \text { fokus pada bisnis dan } \\
\text { operasional } \\
\text { - Belum ada program beasiswa bagi } \\
\text { karyawan } \rightarrow \text { upgrading pendidikan beban } \\
\text { pibadi karyawan. }\end{array}$ & $\begin{array}{l}\text { - Lakukan } \\
\text { kembali TNA } \\
\text { untuk } \\
\text { merancang } \\
\text { program } \\
\text { pelatihan } \\
\text { - Knowledge } \\
\text { Management } \\
\text { - Beasiswa based } \\
\text { on performance }\end{array}$ \\
\hline
\end{tabular}


Tabel 2. Lanjutan

\begin{tabular}{|c|c|c|}
\hline $\begin{array}{l}\text { Strategi } \\
\text { MSDM }\end{array}$ & Kondisi Aktual & Saran Perbaikan \\
\hline $\begin{array}{l}\text { Manajemen } \\
\text { Kinerja }\end{array}$ & $\begin{array}{l}\text { - Belum ada HR Score Card } \rightarrow \text { KPI tidak } \\
\text { ada. } \\
\text { - Item-item penilaian menimbulkan bias } \\
\text { - Subyektifitas tinggi } \\
\text { - Sistem reward dan punishment belum } \\
\text { sepenuhnya berjalan. }\end{array}$ & $\begin{array}{l}\text { - Setup } \\
\text { performance } \\
\text { manajemen } \\
\text { sistem. }\end{array}$ \\
\hline $\begin{array}{l}\text { Pengembangan } \\
\text { Kompetensi }\end{array}$ & $\begin{array}{l}\text { - Job description tidak jelas } \rightarrow \text { overlapping } \\
\text { dan lempar pekerjaan } \\
\text { - Perusahaan tidak memiliki core, soft and } \\
\text { hard competency. }\end{array}$ & $\begin{array}{l}\text { - Job analysis } \\
\text { and job } \\
\text { evaluation } \\
\text { - Setup } \\
\text { Competency } \\
\text { - Work load } \\
\text { analysis }\end{array}$ \\
\hline $\begin{array}{l}\text { Corporate- } \\
\text { Family }\end{array}$ & $\begin{array}{l}\text { - Kegiatan gathering hanya berlaku bagi } \\
\text { karyawan } \rightarrow \text { kegiatan high cost } \\
\text { - Gathering tidak dilakukan sejak krisis } \\
\text { ekonomi perusahaan. }\end{array}$ & $\begin{array}{l}\text { Ciptakan } \\
\text { kegiatan } \\
\text { kebersaman } \\
\text { yang low cost }\end{array}$ \\
\hline $\begin{array}{l}\text { Talent } \\
\text { Manajemen }\end{array}$ & $\begin{array}{l}\text { - Program Manajemen Training tidak efektif } \\
\rightarrow \text { Banyak peserta MT yang tidak di } \\
\text { develop sebagai talent. }\end{array}$ & $\begin{array}{ll}\text { - } & \text { Career } \\
\text { Development } \\
\text { - } \quad \text { Accelerasion } \\
\text { Program } \\
\text { - Ledership } \\
\text { Program }\end{array}$ \\
\hline $\begin{array}{l}\text { Pengurangan } \\
\text { Karyawan }\end{array}$ & $\begin{array}{l}\text { - Masih banyak karyawan usia pensiun } \\
\text { dipekerjakan. }\end{array}$ & $\begin{array}{l}\text { Lakukan } \\
\text { analisa } \\
\text { penisun } \\
\text { - Program } \\
\text { Persiapan } \\
\text { Masa Pensiun }\end{array}$ \\
\hline
\end{tabular}

\section{KESIMPULAN DAN SARAN}

Disimpulkan bahwa semua faktor yang diukur dalam penelitian ini memberikan peran dalam mempengaruhi employee engagement di PT. XYZ, namun faktor lingkungan yang harmonis memiliki persentase tertinggi dalam menciptakan dan mempertahankan karyawan dibandingkan dengan faktor lainnya yaitu sebesar 19,42\%.

Sementara aspek-aspek di bidang SDM yang mendapat perhatian karyawan untuk diperbaiki adalah aspek pelatihan dan pengembangan (21,08\%), pengembangan karir $(20,82 \%)$ dan kompensasi dan benefit $(19,02 \%)$. 
Merancang Strategi Human ... (Eleonora Chrysenny Hutagalung)

Agar rancangan strategi dan implementasi yang sudah disusun penulis berdasarkan hasil temuan dan analisa di atas, maka disarankan agar setiap intervensi tersebut dapat dilaksanakan secara bertahap dan berkesinambungan dengan komitmen dari Manajemen tingkat atas di perusahaan. Sementara untuk efektivitas perancangan, pelaksanaan, penyeliaan dan pengawasan diperlukan merekrut external consultant. 


\section{DAFTAR PUSTAKA}

Amstrong, M. Manajemen Sumber Daya Manusia. Jakarta : Alex Media Komputindo, 1994.

Cook. The Essential : Guide To Employee Engagement - Better Business Performance Through Staff Satisfaction. London, U.K. : Kagon Page, 2008.

Fajar \& Heru. Manajemen Sumberdaya Manusia : Sebagai Dasar Meraih Keunggulan Bersaing. Yogyakarta : UPP STIM YKPN, 2010.

Guntar. "Menghadapi Turn Over : Bagaimana Mempertahankan Karyawan Handal” http://akhmadguntar.com, 2008.

Greenberg, J. \& Baron, R. A. Behavior In Organization. 8th edition. Prentice Hall, 2002.

Handoko, T. H. Manajemen Personalia dan Sumber Daya Manusia. Yogyakarta : BPFE Press, 2001.

Hariandja. Manajemen Sumberdaya Manusia : Pengadaan, Pengembangan, Pengkompensasian, dan Peningkatan Produktivitas Pegawai. Jakarta: PT. Grasindo, 2007.

Hasibuan, M. Manajemen Sumber Daya Manusia. Jakarta : Bumi Aksara, 2003.

Jennifer A. HR How To : Employee Retention, Everything You Need To Know About Creating an Effective Employee Retention Program. Catherine Wolf, 2002.

Julindi. "Pengujian Validitas dan Reliabilitas”. http://www.azuarjuliandi.com, 2007.

Koran Jakarta. “Arpeni Kembali gagal Bayar Kupon Obligasi”. http://www.bataviase.co.id, 2010.

Ma’mun \& Harry. "Employee Engagement : Sebuah kajian Awal.” MBA - ITB Business Review. Vol. 3 No.1 ( 2002).

Nainggolan. “Kerangka Konseptual” http://www.litbang.depkes.go.id 2007.

Siagian. Teori Motivasi dan Aplikasinya. Cetakan Kedua, Jakarta : PT. Rineka Cipta, 1995.

Stoner, F. Definisi, Pengertian, Tugas dan Fungsi Manajemen MSDM - Ilmu Ekonomi Manajemen. http://www.organisasi.org 2006. 